\title{
Parasitoid of the Citrus Leafminer, Semielacher petiolatus (Girault) (Insecta: Hymenoptera: Eulophidae) ${ }^{1}$
}

\author{
Marjorie A. Hoy, Lucia Zappala and Ru Nguyen²
}

\section{Introduction}

The citrus leafminer, Phyllocnistis citrella Stainton (Lepidoptera: Gracillariidae), was first detected in Florida in 1993 (Heppner 1993). This invasive pest spread rapidly throughout the citrus-growing areas and is now well established in Florida. The parasitoid Semielacher petiolatus (Girault) (Hymenoptera: Eulophdae) was introduced during July 2003 into quarantine facilities in the Division of Plant Industry in Gainesville and the Department of Entomology and Nematology in Gainesville, where it is being evaluated for possible release into Florida's citrus to augment the role of the citrus leafminer's other natural enemies.

\section{Classical Biological Control of the Citrus Leafminer in Florida}

The citrus leafminer (CLM) probably originated in Asia and its host range includes citrus species and a few closely-related Rutaceae (Heppner 1993, Knapp et al. 1995). The citrus leafminer has a relatively simple life history: adult males and females emerge in the early morning hours and mate at dusk and females begin to deposit eggs about 24 hours later on tender new leaves $10-20 \mathrm{~mm}$ in length (also called flush) during the night. A single female can deposit approximately 50 eggs during her life. The eggs mature within a day in summer and the young larvae immediately chew their way into the tiny leaf, where each produces a mine. There are three larval stages found within the mine and, after five to six days in summer, the larvae become prepupae, a nonfeeding stage. The prepupa produces silk to form a closed pupal chamber, usually made by folding the edge of the leaf. Molting to the pupal stage occurs within this protected chamber and, after about six days, adults emerge from the end of the chamber. Up to 15 generations per year can occur in tropical conditions (Smith et al. 1997). Because the leafminer must oviposit on and develop within tender new leaves, leafminer populations typically decline during the winter in subtropical climates. It is unknown whether the leafminer has a diapause that allows it to overwinter in regions that have cold winters when there is little new growth to attack.

\footnotetext{
1. This document is EENY-313, one of a series of Featured Creatures from the Entomology and Nematology Department, Florida Cooperative Extension Service, Institute of Food and Agricultural Sciences, University of Florida. Published: November 2003. This document is also available on Featured Creatures Website at http://creatures.ifas.ufl.edu. Please visit the EDIS Website at http://edis.ifas.ufl.edu. Additional information on these organisms, including many color photographs, is available at the Entomology and Nematology Department website at http://entnemdept.ifas.ufl.edu/.

2. Marjorie A. Hoy and Lucia Zappala, Department of Entomology and Nematology, University of Florida, Gainesville and Ru Nguyen, Florida Department of Agriculture and Consumer Services, Division of Plant Industry, Gainesville.
}

The Institute of Food and Agricultural Sciences (IFAS) is an Equal Employment Opportunity - Affirmative Action Employer authorized to provide research, educational information and other services only to individuals and institutions that function without regard to race, creed, color, religion, age, disability, sex, sexual orientation, marital status, national origin, political opinions or affiliations. For information on obtaining other extension publications, contact your county Cooperative Extension Service office. Florida Cooperative Extension Service / Institute of Food and Agricultural Sciences / University of Florida / Larry R. Arrington, Interim Dean 
Additional information on the citrus leafminer can be found at:

Classical biological control of the citrus leafminer in Florida,

Classical biological control of the citrus leaf miner in Florida: a progress report.

In Florida, a variety of natural enemies cause significant mortality to the citrus leafminer (Amalin and Pena 1999, Browning and Pena 1995, Pena et al. 1996). Several eulophid parasitoid species, already present in Florida when the citrus leafminer invaded, moved on to this new food source (Pena et al. 1996, Schauff et al. 1998, Evans 1999). However, natural enemies from Asia were known to be effective and a classical biological control program was initiated in 1994 (Hoy and Nguyen 1997). Ageniaspis citricola Loginovskaya and Cirrospilus ingenuus Gahan were introduced from Australia into Florida in 1994 and, after evaluation in quarantine, were released (Hoy and Nguyen 1997). Semielacher petiolatus also was introduced into quarantine from Australia at that time but, because resources were limited, the S. petiolatus colony could not be maintained.

Ageniaspis citricola was released first and established rapidly, spreading throughout the state (Hoy and Nguyen 1994, 1997; Hoy et al. 1995, 1997; Pomerinke and Stansly 1998). Ageniaspis is considered a specialist on the citrus leafminer and does not attack other insect species to any significant degree. As a result, when citrus leafminer population densities are low during the winter, A. citricola has to search intensely for the very rare eggs and first instar larvae of the citrus leafminer on the very limited number of tender new shoots.

Cirrospilus ingenuus (originally released as $C$. quadristriatus) also was released in Florida citrus (Hoy and Nguyen 1994, 1997) and subsequently established in south Florida (LaSalle et al. 1999). However, $C$. ingenuus appears to be rare in citrus groves outside the Homestead area (Hoy and Nguyen, unpublished). Cirrospilus ingenuus is considered relatively restricted in its host range to the citrus leafminer, although Zhu et al. (2002) reported that it parasitized lyonettid leafminers in citrus in China.
Additional information on the Cirrospilus can be found at:

Classical Biological Control of the Citrus Leafminer: Release of Cirrospilus quadristriatus.

In Florida, where rainfall occurs throughout the year, citrus typically has four or five major intervals when new growth (or flush) is produced; typically, flushes occur during February-March, May, June, July-August, September-October

(Villanueva-Jimenez et al. 1998). Because citrus leafminer populations decline to nearly undetectable levels over the winter, the first flush interval has very few citrus leafminers and a relatively low rate of parasitism by A. citricola (Villanueva- Jimenez et al. 1998, Zappala et al., unpublished). Citrus leafminer populations typically increase in the second flush and, if A. citricola populations lag behind, this generation of the leafminer can increase dramatically. A. citricola is quite susceptible to drought conditions (Yoder and Hoy 1998), and this could have contributed to its reduced ability to suppress leafminer populations during some recent dry springs in flush intervals 2 and 3. By August, and throughout the fall in Florida, citrus leafminer populations typically exhibit high rates of parasitism by $A$. citricola and leafminer populations are often well below the densities seen during the second flush.

To improve the suppression of citrus leafminer populations during the second flush interval in Florida, at least two options are available. One would be to monitor leafminer populations during the spring and apply a pesticide that reduces leafminer populations without disrupting the natural enemies that suppress them (as well as other insect and mite pests). Options include several IPM- compatible pesticides (Villanueva-Jimenez and Hoy. 1998a, 1998b). Alternatively, an additional parasitoid could be introduced in a classical biological control program which, if established, might augment the suppression of citrus leafminer populations during the critical second flush interval in spring.

Ideally, the introduced parasitoid would not disrupt populations of $A$. citricola by acting as a facultative hyperparasitoid so tests should be conducted on any candidate species in quarantine to confirm that the new parasitoid does not prefer to 
attack leafminers parasitized by $A$. citricola over unparasitized leafminers. If the new parasitoid shows restraint (does not often attack leafminers parasitized by $A$. citricola) or does not discriminate (attacks approximately equal numbers of leafminers parasitized by $A$. citricola), then the new parasitoid would not likely disrupt the effectiveness of $A$. citricola unless it out competes A. citricola for scarce hosts during the winter.

A second desirable attribute of any newly introduced parasitoid is that it should overwinter more successfully than A. citricola under Florida conditions. The ability of the parasitoid to enter diapause or to survive on alternative leafminer hosts could improve its ability to suppress leafminer populations early in the growing season when $A$. citricola populations are least abundant.

The following discussion describes what is known about one candidate for release in Florida as part of a continuing classical biological control program against the citrus leafminer. Semielacher petiolatus was kindly shipped to us by Dr. G. Siscaro, University of Catania, Italy, and imported into quarantine in Gainesville during July 2003.

\section{Biology of Semielacher petiolatus}

Semielacher petiolatus prefers to attack secondand third-instar larvae of the citrus leafminer, but it can also parasitize fourth instars (= prepupae) (Mineo and Mineo 1999a, 1999b). In addition to killing citrus leafminers by parasitism, adult females kill by host feeding, in which the female sticks her ovipositor into the larva, then drinks the hemolymph (Argov and Rossler 1998).

Adults of $S$. petiolatus are 1-2 $\mathrm{mm}$ long, the female is brown with a yellow abdomen and the male's abdomen is brown at the tip. Semielacher petolatus is a solitary ectoparasitic wasp and females deposit eggs near or on the larvae of their hosts (Boucek 1988, Argov and Rossler 1998). Semielacher females apparently inject venom into the citrus leafminer and the larvae subsequently can't move or feed. The parasitoid larva hatches and feeds on the citrus leafminer, finally pupating within the leafminer's mine (or within the pupal chamber if the host was a prepupa when parasitized). There is no published information as to how many citrus leafminer larvae are killed by host feeding and how many by parasitism. Semielacher petiolatus completes its life cycle in about 10 days at $25^{\circ} \mathrm{C}$. Both males and females are produced, with a female-biased sex ratio. Mineo and Mineo (1999b) suggested that males are produced when second-instar hosts are parasitized and females are produced from third- and fourth-instar leafminer larvae.

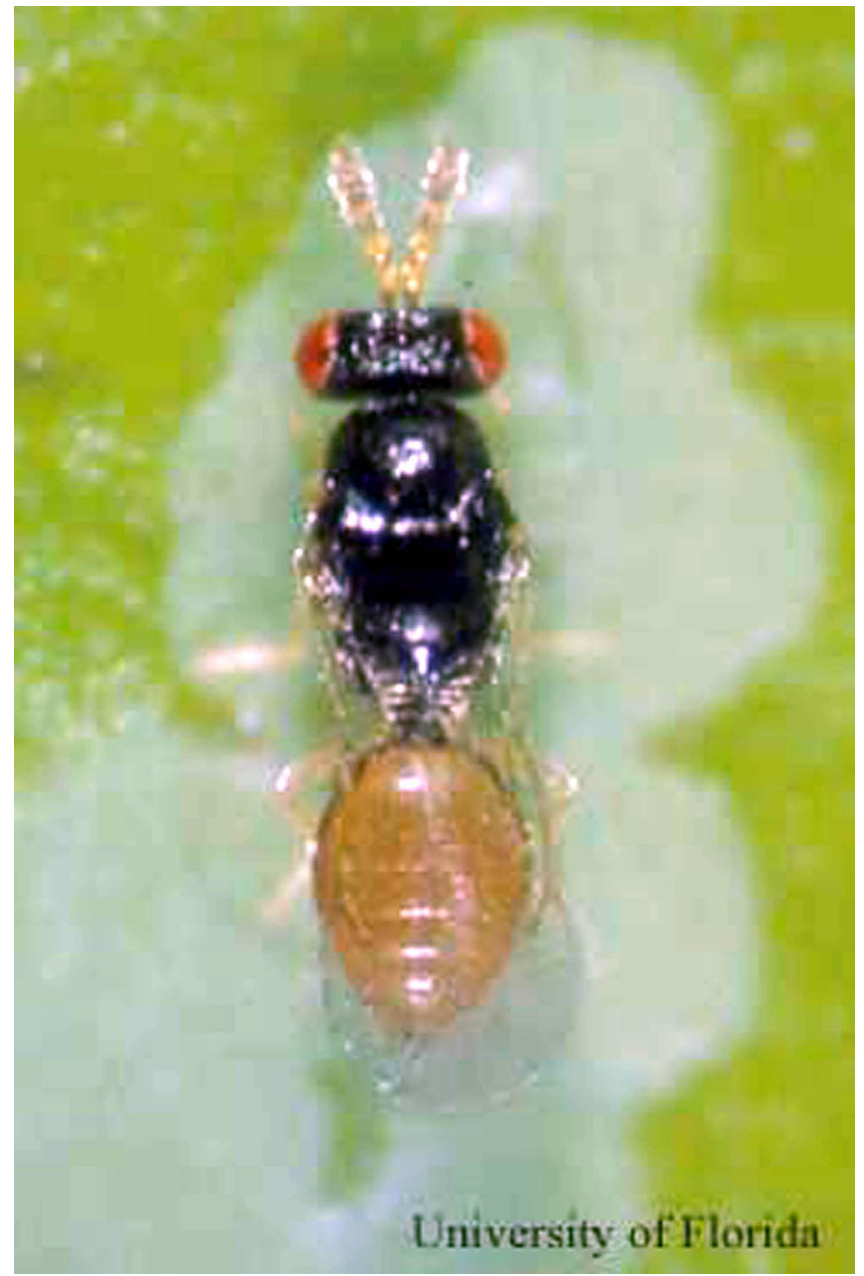

Figure 1. Adult female Semielacher petiolatus (Girault), an ectoparasitoid of the citrus leafminer, Phyllocnistis citrella Stainton. Credits: Photograph by: L. Zappala, University of Florida

Semielacher petiolatus has been found attacking the citrus leafminer in Australia (Boucek 1988, Smith et al. 1997) and in the Solomon Islands (Schauff et al. 1998), where the parasitoid was considered to be endemic. Semielacher petiolatus has been introduced into other areas where the citrus leafminer has invaded citrus, including Cyprus, Israel, Morocco, 


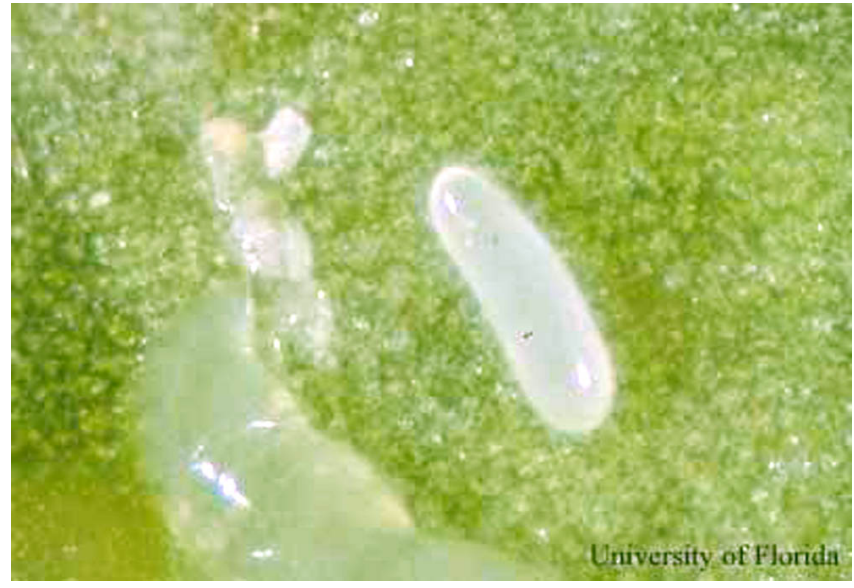

Figure 2. Egg of Semielacher petiolatus (Girault), an ectoparasitoid of the citrus leafminer, Phyllocnistis citrella Stainton, in a citrus leafminer mine. Credits: Photograph by: L. Zappala, University of Florida

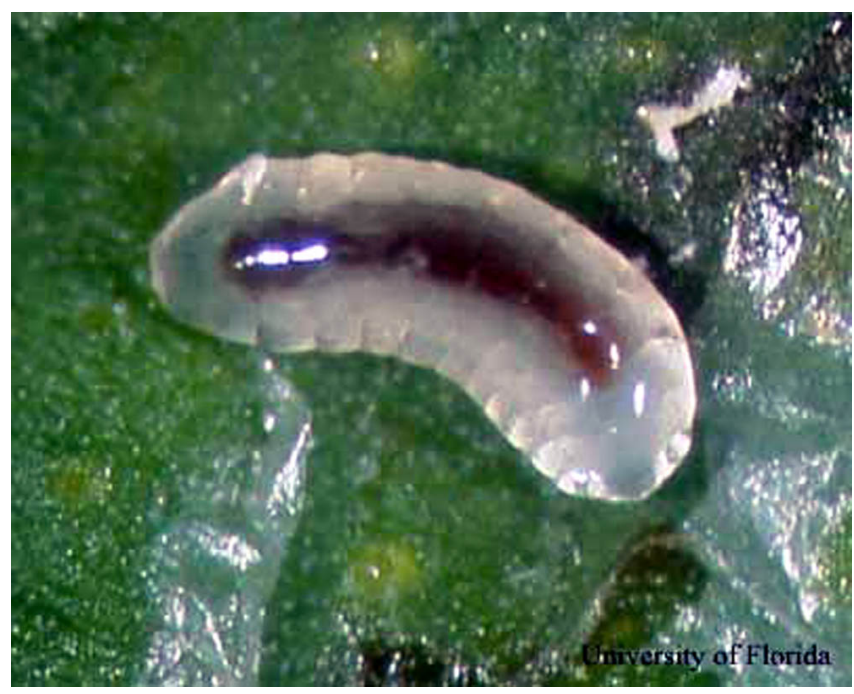

Figure 3. Larva of Semielacher petiolatus (Girault), an ectoparasitoid of the citrus leafminer, Phyllocnistis citrella Stainton. Credits: Photograph by: L. Zappala, University of Florida

Oman, Syria, Tunisia, Turkey, Egypt, Greece and Spain (Schauff et al. 1998).

Semielacher petiolatus appears to be able to attack leafminer species other than the citrus leafminer, although at low rates. Semielacher petiolatus was first found in Italy in 1998, but it is unknown how it arrived there (Mineo et al. 1998). By 2001, S. petiolatus appeared to be the most efficient parasitoid of the citrus leafminer in Italy, with parasitism levels reaching nearly $80 \%$. In 2002 , S. petiolatus was recovered in all citrus-growing areas of Sicily with most of its activity occurring on citrus leafminer populations in early summer (June-August)

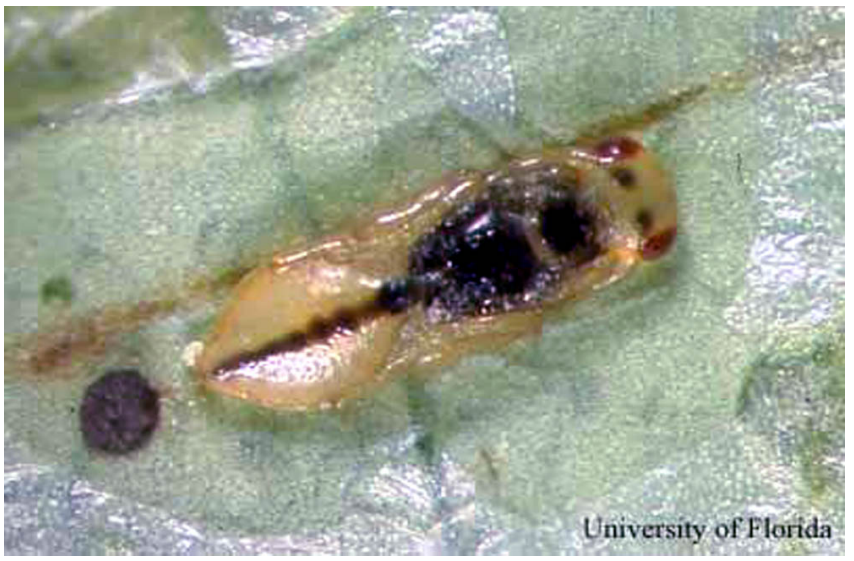

Figure 4. Pupa of Semielacher petiolatus (Girault), an ectoparasitoid of the citrus leafminer, Phyllocnistis citrella Stainton. Credits: Photograph by: L. Zappala, University of Florida

while parasitism rates of the introduced eulophid Citrostichus phyllocnistoides Narayanan were higher in the later part of the growing season (September-October) (Siscaro et al. 2002). Siscaro et al. (2002) suggested that the establishment of $S$. petiolatus (and of Citrostichus phyllocnistoides) was "related to the presence of alternative hosts" and that "their seasonal alternation could be partly explained by the different biological and ecological attitudes these two species showed on hosts of native flora." Siscaro et al. (2002) concluded it is "important to maintain a rich biodiversity in citrus groves in order to provide alternative food and shelter to CLM parasitoids, mainly in winter and spring, when CLM populations are at their minimum levels."

Mineo (1999) reported that S. petiolatus was observed overwintering on the citrus leafminer in Sicily and that $S$. petiolatus was found in all its developmental stages during January and February 1999, suggesting that this parasitoid may not have a diapause.

\section{Taxonomic Description of Semielacher petiolatus}

Keys to the families of Chalcidoidea can be found at:

http://www.nhm.ac.uk/entomology/chalcidoids/ eulophidae1.html. According to the Chalcidoidea Database, the family Eulophidae contains 297 genera and 4472 species in 4 subfamilies. The majority of the Eulophidae are primary parasitoids of concealed 
larvae, especially those inhabiting leaf mines. The best known species attack Lepidoptera, but eulophids also may attack larvae of Diptera (Agromyzidae), Hymenoptera (heterarthrine Tenthredinidae) and Coleoptera (Curculionidae).

The genus Semielacher Boucek is in the subfamily Eulophinae, which are "solitary or gregarious idiobiont ectoparasitoids of the larvae of leafminers or of concealed hosts such as leaf folders case bearers, gall makers and stem borers. Many species are facultative or obligate hyperparasitoids of other chalcids, braconids or ichneumonids" (Chalcidoidea Database). The genus Semielacher contains a total of two species according to the Chalcidoidea database, but Boucek (1988) indicated the genus Semielacher contains a total of three species from Australia, with two also present from New Guinea. According to Schauff et al. (1998), Semielacher is known only from Australasia. In Papua, New Guinea one undescribed species was reared as a parasite of the citrus leafminer.

Parasitoids in the genus Semielacher Boucek have 4-segmented tarsi and a funicle that is 2-segmented (Schauff et al. 1998).

Smith et al. (1997) describe S. petiolatus as indigenous to Australia and note it is the major parasite attacking the citrus leafminer in drier parts of the citrus growing areas, but it is also important in Queensland (a subtropical citrus-growing area), along with the introduced encyrtid, Ageniaspis citricola.

\section{Host Range of S. petiolatus}

Information on the host range of S. petiolatus is based on records of material collected from field samples and, in Asia, it has been recorded only from the citrus leafminer. Elsewhere, the incidence of parasitism in hosts other than the citrus leafminer appears to be low, but the data serve as an indicator of potential host range.

Semielacher petiolatus was found on Chromatomyia horticola (Goureau) (Diptera: Agromyzidae) in Sicily about one year after its release in 1996 in Tunisia (Massa et al. 2001). Massa et al. (2001) concluded that the rapid spread and establishment of S. petiolatus in Sicily could be due to its ability to find alternative hosts that provide refuge and food for S. petiolatus during seasons of low citrus leafminer population density.

Rizzo (2002) indicated that $S$. petiolatus has been collected from several hosts on native plants in Italy, and that this "helps in maintaining populations of both native and exotic parasitoid, mainly in the seasons of low availability of $P$. citrella larvae."

Massa et al. (2001) evaluated species of leafminers found on approximately 40 of the most common plants associated with citrus groves in Sicily between 1997 and 2000. Leaves infested with miners were held in the laboratory until the insects and their parasitoids emerged; parasitoids found included $S$. petiolatus, C. phyllocnistoides and C. ingenuus, which "possibly have switched over onto indigenous hosts after their introduction or immigration." The dipteran Agromyza hiemalis Becker (Diptera: Agromyzidae), a leafminer of nettle (Urtica), served as a new host of S. petiolatus in Sicily (Massa and Rizzo 2000). Massa et al. (2001) indicated that $S$. petiolatus could be found on five new hosts, including three Lepidoptera (Cosmopterigidae, Nepticulidae and Gracillariidae) and two Diptera (Agromyzidae) (Table 1).

Table 1. List of host records for Semielacher petiolatus on native plants in Italy and Jordan (Massa et al. 2001).

\begin{tabular}{||l|l|l|l||}
\hline \multicolumn{1}{|c|}{$\begin{array}{c}\text { Host Insect } \\
\text { Family }\end{array}$} & Host Plant & \multicolumn{1}{|c||}{ Site } & Sex \\
\hline $\begin{array}{l}\text { Chromatomyia } \\
\text { horticola } \\
\text { Agromyzidae }\end{array}$ & $\begin{array}{l}\text { Sonchus } \\
\text { spp. }\end{array}$ & $\begin{array}{l}\text { Palermo, } \\
\text { Italy }\end{array}$ & $\begin{array}{l}2 \\
\text { males }\end{array}$ \\
\hline $\begin{array}{l}\text { Liriomyza sp. } \\
\text { Agromyzidae }\end{array}$ & $\begin{array}{l}\text { Mercurialis } \\
\text { annua }\end{array}$ & $\begin{array}{l}\text { Palermo, } \\
\text { Italy }\end{array}$ & $\begin{array}{l}1 \\
\text { female }\end{array}$ \\
\hline $\begin{array}{l}\text { Cosmopterix } \\
\text { pulchrimella } \\
\text { Cosmopterigidae }\end{array}$ & $\begin{array}{l}\text { Parietaria } \\
\text { diffusa }\end{array}$ & $\begin{array}{l}\text { Palermo, } \\
\text { Italy }\end{array}$ & $\begin{array}{l}4 \\
\text { females }\end{array}$ \\
\hline $\begin{array}{l}\text { Stigmella aurella } \\
\text { Nepticulidae }\end{array}$ & $\begin{array}{l}\text { Rubus } \\
\text { ulmifolius }\end{array}$ & $\begin{array}{l}\text { Palermo, } \\
\text { Italy }\end{array}$ & $\begin{array}{l}1 \\
\text { female }\end{array}$ \\
\hline $\begin{array}{l}\text { Dialectica } \\
\text { sclariella } \\
\text { Gracillariidae }\end{array}$ & Echium sp. & Jordan & $\begin{array}{l}1 \\
\text { female }\end{array}$ \\
\hline \hline
\end{tabular}

Semielacher petiolatus and C. phyllocnistoides were found parasitizing native hosts at a low rate, "compared with the whole number of parasitoids (564) obtained" during the project (Massa et al. 
2001). Massa et al. (2001) concluded from a "qualitative point of view it seems that the community structure of parasitoids did not change after the introduction of exotic species" (Massa et al. 2001). Thus, at least in Sicily, there is no evidence that these two citrus leafminer parasitoids altered the abundance of other parasitoids within and around citrus groves. What is unknown is whether the community of parasitoids attacking leafmining insects on host plants outside citrus groves was affected. Other questions include: Are $S$. petiolatus and $C$. phyllocnistoides attacking agromyzid leafminers in vegetables and other crops in Sicily? Would Semielacher, if established in Florida, attack other leafminer species? Would this alter the effectiveness of already-established parasitoids of these leafminers?

\section{Expected Attainable Geographic Range in North America}

Based on current knowledge of the biology of $S$. petiolatus, its expected geographic range will be where the citrus leafminer is established in citrus in the USA, which includes Florida, Louisiana, Texas and California. Semielacher petiolatus appears to be able to establish in a diversity of climates, ranging from Mediterranean to subtropical. Semielacher petiolatus also may attack other leafminer species, including dipterans, on host plants other than citrus. We do not expect it to colonize temperate regions where winters are below freezing for any length of time. We have no detailed data on temperature or relative humidity tolerances of $S$. petiolatus, however.

\section{Expected Environmental Effects of $S$. petiolatus in Florida}

Semielacher petiolatus is expected to establish on the citrus leafminer and to reduce citrus leafminer populations. Ideally, it would be most effective against citrus leafminer populations in the early spring in Florida. The use of pesticides to control the citrus leafminer could be reduced, leading to fewer negative effects on a variety of natural enemy species in citrus, or negative effects on the ground water, workers, or consumers.
It is unlikely that $S$. petiolatus would have significant negative effects on beneficial species of insects, such as honeybees. No dipteran or lepidopteran leafminers in Florida have been declared to be threatened or endangered.

The potential interactions, under Florida conditions, between $S$. petiolatus and any other parasitoids are difficult to predict and are discussed below. One could argue that if $S$. petiolatus were to overwinter in dipteran leafminer species such as Liriomyza trifolii, a pest of vegetables, it might augment control of Liriomyza; alternatively, $S$. petiolatus might compete with the alreadyestablished parasitoids of $L$. trifolii and reduce their effectiveness.

\section{Potential Effects of S. petiolatus on Other Insects in Florida}

Based on the data from Sicily (Table 1), in which $S$. petiolatus was found attacking leafminers in weeds in citrus groves, $S$. petiolatus could attack both lepidopteran and dipteran leafminers in Florida. Hosts could include: 1) leafminers on plants of no economic importance; 2) leafminers on weeds; or 3) leafminer species, such as Liriomyza trifolii, that are serious pests of vegetable crops. Parkman et al. (1989) evaluated the leafminers and their parasitoids on selected weeds in south Florida; both Liriomyza trifolii and L. sativae were found on weed hosts in south Florida, with the most abundant parasitoids and leafminers found on castor bean, Ricinus communis L. The weeds were considered to be reservoirs for parasitoids which could possibly enhance the biological control of $L$. trifolii in vegetable crops.

There is a possibility that $S$. petiolatus could use L. trifolii or $L$. sativae as alternative hosts, especially during the winter, when citrus leafminer populations are very low. S. petiolatus could, during the winter, compete with other established parasitoids of Liriomyza species. Whether this could alter the effectiveness of the established Liriomyza parasitoids is unknown. 


\section{Pesticide Selectivity}

No tests have been conducted to determine which pesticides can be used safely without disrupting $S$. petiolatus populations in citrus groves. However, based on laboratory and field tests conducted in Florida on Ageniaspis citricola, oil and copper (Kocide) are IPM-compatible, meaning that A. citricola can persist if these products are used for insect, mite and disease control (Villanueva-Jimenez et al. 1998; Villanueva-Jimenez and Hoy 1998a). Other potential IPM-compatible products that will not disrupt establishment and persistence of S. petiolatus may include: azadirachtin (Neemix) $+0.4 \%$ oil, and fenoxycarb (Eclipse) $+0.4 \%$ oil.

\section{Selected References}

Amalin DM, Pena JE. 1999. Predatory spiders in lime orchards and their importance in the control of citrus leafminer, Phyllocnistis citrella (Lepidoptera: Gracillariidae). Proceedings of the Florida State Horticultural Society 112: 222-224.

Argov Y, Rossler Y. 1998. Rearing methods for the citrus leafminer Phyllocnistis citrella Stainton and its parasitoids in Israel. Biological Control 11: 18-21.

Browning H, Pena JE. 1995. Biological control of the citrus leafminer by its native parasitoids and predators. Citrus Industry 76(4): 46-48.

Boucek Z. 1988. Australasian Chalcidoidea (Hymenoptera). A Biosystematic Revision of Genera of Fourteen Families, with a Reclassification of Species. Wallingford: CAB International.

Evans GA. (1999). A new species of Cirrospilus (Hymenoptera: Eulophidae) and two new synonymies of parasitoids reared from the citrus leafminer, Phyllocnistis citrella (Lepidoptera: Gracillariidae). Florida Entomologist. http://www.fcla.edu/FlaEnt/fe82p448.pdf (31 October 2003).

Heppner JB. 1993. Citrus leafminer (CLM) Phyllocnistis citrella Stainton, in Florida (Lepidoptera: Gracillariidae: Phyllocnistinae). Tropical Lepidoptera 4: 49-64.
Hoy MA, Nguyen R. 1994. Classical biological control of the CLM: Release of Cirrospilus quadristriatus. Citrus Industry 75 (11): 14.

Hoy MA, Nguyen R. 1997. Classical biological control of the citrus leafminer Phyllocnistis citrella Stainton (Lepidoptera: Gracillariidae): Theory, practice, art, and science. Tropical Lepidoptera 8 (Suppl. 1): 1-19.

Hoy MA, Nguyen R, Hall D, Pomerinke M, Pena J, Browning H, Stansly P. 1995. Establishment of citrus leafminer parasitoid. Ageniaspis citricola in Florida. Citrus Industry 76 (11): 12-17.

Hoy M., Nguyen R, Pomerinke M, Bullock R, Hall D, Knapp J, Pena J, Browning H, Stansly P. 1997. Distribution and abundance of Ageniaspis citricola, a parasite of the citrus leafminer in Florida. Citrus Industry 78(5): 51-52.

Knapp JL, Albrigo LG, Browning HW, Bullock RC, Heppner JB, Hall DG, Hoy MA, Nguyen R, Pena JE, Stansly PA. 1995. Citrus leafminer, Phyllocnistis citrella Stainton: Current Status in Florida - 1994. Florida Cooperative Extension Service, IFAS, University of Florida, Gainesville, 26 pp.

LaSalle J, Duncan, RE, Pena, JE. (1999). The recovery and apparent establishment of Cirrospilus ingenuus (Hymenoptera: Eulophidae) in Florida. Florida Entomologist. http://www.fcla.edu/FlaEnt/fe82p371.pdf (31 October 2003).

Massa B, Rizzo MC. 2000. Agromyza hiemalis Becker (Diptera, Agromyzidae) leafminer of nettle (Urtica spp): phenology and parasitoids in Italy. Phytophaga 10: 53-67.

Massa B, Rizzo MC, Caleca V. 2001. Natural alternative hosts of Eulophidae (Hymenoptera: Chalcidoidea) parasitoids of the citrus leafminer Phyllocnistis citrella Stainton (Lepidoptera: Gracillariidae) in the Mediterranean basin. Journal of Hymenopteran Research 10: 91-200.

Mineo G. 1999. Records on indigenous antagonists of Phyllocnistis citrella Stainton (Lepidoptera Gracillariidae) new for Italy. Bollettino 
Zoologia agraria e Bachicoltura Serie II, 31(1): 97-105.

Mineo G, Mineo N. 1999a. Introduzione di Citrostichus phyllocnistoides (Narayanan) in Sicilia e suo allevamento simultaneo con Semielacher petiolatus (Girault) (Hym. Eulophidae). Bollettino Zoologia agraria e Bachicoltura, Serie II 31 (2): 197-206.

Mineo G, Mineo N. 1999b. Ulteriori dati sull'acclimatazione di Semielacher petiolatus (Girault) (Hym. Eulophidae) in Sicilia. Bollettino Zoologia agraria e Bachicoltura, Serie II 31(2): 235 239.

Mineo G, Caleca V, Massa B. 1998. Semielacher petiolatus (Girault) (Hymenoptera Eulophidae), natural antagonist of Phyllocnistis citrella Stainton (Lepidoptera Gracillariidae), new for italian entomofauna. Il Naturalista siciliano 22: 3-6.

Parkman P, Dusky JA, Waddill VH. 1989. Leafminer and leafminer parasitoid incidence on selected weeds in south Florida. Florida Entomologist 72: 559-561.

Pena JE, Duncan R, Browning H. 1996. Seasonal abundance of Phyllocnistis citrella (Lepidoptera: Gracillariidae) and its parasitoids in south Florida citrus. Environmental Entomology 25: 698-702.

Pomerinke MA, Stansly PA. (1998). Establishment of Ageniaspis citricola (Hymenoptera: Encyrtidae) for biological control of Phyllocnistis citrella (Lepidoptera: Gracillariidae) in Florida. Florida Entomologist. http://www.fcla.edu/FlaEnt/fe81p361.pdf (31 October 2003).

Rizzo MC. 2002. Tri-trophic interactions involving eulophid parasitoids (Hymenoptera, Eulophidae) of the citrus leafminer Phyllocnistis citrella Stainton. Presentation 6, IOBC/WPRS Citrus Working Group, Valencia Spain, Nov. 2002.

Schauff ME, LaSalle J, Wijesekara GA. 1998. The genera of chalcid parasitoids (Hymenoptera: Chalcidoidea) of citrus leafminer Phyllocnistis citrella Stainton (Lepidoptera: Gracillariidae). Journal of Natural History 21: 1001-1056.
Siscaro G, Caleca V, Reina P, Rizzo MC, Zappala L. 2002. Current status of the biological control of the citrus leafminer in Sicily. Presentation 5, International Organization for Biological Control/Citrus Working Group, Valencia, Spain, November 2002.

Smith D, Beattie GAC, Broadley R. Eds. 1997. Citrus Pests and Their Natural Enemies: Integrated Pest Management in Australia. Queensland Department of Primary Industries.

Villanueva-Jimenez JA, Hoy MA. 1998a. Constraints on developing an integrated pest management program for citrus leafminer (Lepidoptera: Gracillariidae) in Florida nurseries. HortTechnology 8 (3): 332-345.

Villanueva-Jimenez JA, Hoy MA. 1998b. Toxicity of pesticides to the citrus leafminer and its parasitoid Ageniaspis citricola evaluated to assess their suitability for an IPM program in citrus nurseries. BioControl 43: 357-388.

Villanueva-Jimenez JA, Hoy MA, Davies FS. 1998. Leafminer: Preliminary IPM program for nurseries. Citrus Industry 79 (7):34, 35, 37, 38.

Yoder JA, Hoy MA. 1998. Differences in water relations among the citrus leafminer and two different populations of its parasitoid inhabiting the same apparent microhabitat. Entomologia Experimentalis et Applicata 89: 169-173.

Zhu CD, LaSalle J, Huang DW. 2002. A study of Chinese Cirrospilus Westwood (Hymenoptera: Eulophidae). Zoological Studies 41: 23-46. 